\title{
Personal Memories of Donald A.B. Lindberg M.D., Visual Thinker and Medical Visionary
}

\author{
Thomas G. WEST ${ }^{1}$ \\ Washington D.C. U.S.A.
}

\begin{abstract}
Keywords. Donald A.B. Lindberg M.D., visual thinking, computer graphics technology, dyslexia, U.S. National Library of Medicine
\end{abstract}

\section{Introduction}

From the late 1980s until his retirement in 2015, I was privileged to observe the forwardthinking and astonishing depth, range, and liveliness of the National Library of Medicine (NLM) under the direction of Donald A. B. Lindberg M.D.

As an outsider, I observed from my point of view as an ordinary library researcher. I mainly utilized NLM's History of Medicine collections for information about innovative scientists like Michael Faraday and medical pioneers such as Dr. Harvey Cushing. Initially, I used the old paper index catalog cards, microfilm, and the early NLM mainframe computer information systems to research and prepare the manuscript for my first book, In the Mind's Eye, published in spring 1991 [1].

I first met Dr. Lindberg at a gathering after a lecture in NLM's Lister Hill Building. He asked about my work. I explained that my research focus concerned the talents of dyslexic individuals - together with visual thinking in the history of medicine and science. I was surprised to discover that Dr. Lindberg also was interested in these topics.

I later learned that these interests were partly a reflection of his personal history. Don's father was an architect. Don was trained in a highly visual specialty, pathology, and some family members were dyslexic. As is often the case, this kind of personal history helps some to understand and appreciate the puzzling mixed strengths and weaknesses that accompany these life patterns.

I also was fascinated that Don's interests included then-rapidly developing computer graphic technologies as well as the hidden talents of dyslexics (who often see things differently) to innovate and sometimes make scientific discoveries before conventionally trained experts in some fields. Over time, I began to appreciate that Dr. Lindberg had a remarkable ability to see where things were going and attract highly talented and creative people for his staff, NLM's Board of Regents, and the Library's diverse, inventive projects.

Over the years, Dr. Lindberg assumed leadership positions in several major areas archiving massive amounts of genetic code information (within the National Center for Biomedical Information), providing research information in clinicaltrials.gov, and even leading a federal government-wide effort - the High-Performance Computing and

\footnotetext{
${ }^{1}$ Corresponding author: thomasgwest $@$ gmail.com
} 
Communications Program (HPCC). He once remarked to me how difficult it was to deal with 500 HPCC emails a day.

Dr. Lindberg's interest in visual thinking and dyslexia was evidenced when he asked me to be the after-dinner speaker at a meeting of NLM's Board of Regents [2]. He accorded me the honor of describing the ideas I developed during my research and writing. I began my BOR speech with these words:

"My talk this evening is about a return to visual thinking. My subtitle 'new technologies, old talents and reversed expectations,' encapsulates my main thesis - that as we begin to use the newest technologies in really powerful ways (which we have hardly begun), we will begin to tap into some of our oldest and most "primitive" neurological (visual spatial) talents. In so doing, we will begin to see ourselves and our world with very different eyes - leading, in time, to fundamentally different attitudes towards education and concepts of intelligence, as well as the skills and talents that are considered to be the most valuable. ..."

\section{Advanced Applications}

At NLM in the late 1980s and early 1990s, I witnessed the rapid changes in computer systems happening worldwide. Dr. Lindberg seemed to be simultaneously interested in the newest technologies, and at the same time, he respected the insights and sophisticated knowledge of early researchers and traditional cultures.

For example, one morning I chanced to attend another lecture in NLM's Lister Hill Building. The speaker was a sleepy young computer programmer and software engineer. He had been up all night, as he said, releasing to the World Wide Web thousands of copies of a new computer program he and a coworker designed - called a 'browser.'

As it turned out, it was 'Mosaic,' the first web browser of its kind. The young speaker was Marc Andreessen, then working at the National Center for Supercomputing Applications at the University of Illinois. Later, he became famous in the computer world for Netscape and the Silicon Valley venture-capital firm Andreessen Horowitz. Of course, these initiatives helped enable access to the Internet. They revolutionized mass communication - and I was privileged to see the very first day - primarily because of NLM and its forward-thinking director.

\section{Thinking Like Einstein on the Hokule'a}

During his career, Dr. Lindberg became known as a significant innovator in using computers for healthcare research and practice. Under his direction, NLM pioneered broad access to medical information with Medline and PubMed. But Don also promoted a deeper understanding of less well-known groups with programs such as 'Women in Medicine' and 'Native Voices.'

'Native Voices' exemplified how Dr. Lindberg promoted the investigation of the traditional forms of medicine, widely ignored previously. In later years, I was thrilled to see that NLM played a significant role in a visit to Washington, D.C., during the roundthe-world journey of the traditional Polynesian canoe, the Hokule'a - a double-hulled sailing canoe that enabled the early Polynesian peoples to travel among the islands of the broad Pacific Ocean. 
I was delighted to see Dr. Lindberg's interest in this area. Previously, I followed the renewed practice of traditional navigation methods and the significant influence of its rebirth in generating pride and reviving traditional Polynesian culture. Of course, the early traditional navigators used the stars and other natural signs. However, traditional navigators also taught themselves to feel long-distance ocean swells to maintain a heading - and how the absence of 'shadow' in these swells could indicate the presence of an island, out of sight, over the horizon. I wrote about these insights in my second book, Thinking Like Einstein [3]. Indeed, the intended full title for the second book was to have been: Thinking Like Einstein on the Hokule'a.

Dr. Lindberg was well aware of how traditional cultures used visual abilities in highly sophisticated ways - with a minimum of technology and a sophisticated integration of profoundly understood natural forces. I was amazed and delighted when the Hokule'a tied up for several days at the Washington Canoe Club on the Potomac River in the middle of Washington, DC. Nainoa Thompson, the chief traditional navigator, gave a major talk at NLM about traditional navigation methods.

Like Andreessen, NLM provided a stage for an important person (who was not well known outside of Polynesia) to provide fresh perspectives and ideas. In a way, both talks were so typical of Dr. Lindberg's NLM.

Moreover, I enjoyed several conversations with Nainoa at the Canoe Club, where he confirmed his special visual-spatial skills in traditional navigation probably were linked to his dyslexia. We talked about our everyday dyslexia experiences and the dyslexia of some family members. It all seemed to support the theory from Harvard neurologist and dyslexia researcher Norman Geschwind, M.D., who suggested the visual-spatial abilities often seen among dyslexics yielded an array of socio-cultural benefits [4].

\section{Dr. Lindberg's Prescient Leadership}

Over time, I beheld how prescient Dr. Lindberg was in providing leadership during an era of enormous change and rapid progress. Don used his broad interests and deep understanding of the potential of computer systems in the service of medical knowledge and practice.

One especially forward-looking conference was organized in mid-February 2000. At Dr. Lindberg's direction. The 'Visualization Research Agenda Meeting - The Impact of Visualization Technologies - Using Vision to Think' considered how: 'new visualization technologies are giving us new ways of seeing and understanding: bringing diverse worlds together, transforming the nature of education and work, redefining what we understand is talent and intelligence.' The meeting focused on the implications of visualization technology for education and professional training, as well as how to build an appropriate research program.

It was a small but diverse meeting with only 22 attendees. NLM's participants included Dr. Lindberg, Alexa McCray, Michael Ackerman, and Steve Phillips. Other attendees represented: five institutes at the U.S. National Institutes of Health; two from the Smithsonian Institution; three from computer graphics organizations; and six persons with knowledge and experience regarding dyslexia, giftedness, and the brain's evolution.

Among those in attendance was Alvy Ray Smith, Ph.D., a strong advocate for the power of computer graphics in many spheres. Dr. Smith was one of the two founders of the Pixar Animation Studios in Emeryville, CA. Dr. Smith was a member of NLM's Board of Regents and helped with the Visible Human Project and other related programs. 
Other attendees included William J. Dreyer, Ph.D., California Institute of Technology, who provided a striking example of the power of dyslexic visual thinking in science and medicine. Dr. Dreyer had been a classic dyslexic when young; his reading, spelling, and arithmetic assessment scores were substandard. But having performed well on other tests, Dr. Dreyer went on to study biology - and gradually realized he could tell his professors what experiments to do and what the results would be.

Previously, Dr. Dreyer revealed that his dyslexic imagination enabled him to visualize molecular biology and chemistry processes that led to a new and controversial theory about the human immune system. Dr. Dreyer espoused the theory for about 12 years - providing concepts based on data from instruments that he designed and built himself. However, Dr. Dreyer's data was in a form so new and unconventional that almost everyone in his field could not understand what he was talking about.

Years later, Dr. Dreyer was vindicated and proven correct. When Susumu Tonegawa was awarded a Nobel Prize (physiology or medicine, 1987) for work he had done in Switzerland, his innovative sequencing work demonstrated (through experiments that were illegal in the U.S. at the time) that Dreyer and his colleague's predictions were correct. In the words of two scientific historians of this period: 'This experiment marked the point of no return for the domination of the antibody diversity question by nucleotide studies: it was Susumu Tonegawa's final proof of the Dreyer-Bennett V-C translocation hypothesis through the use of restriction enzymes' [5].

Dr. Lindberg's views on dyslexic insight were summarized in a quotation he kindly provided for the back cover of my third book, Seeing What Others Cannot See.

'West argues convincingly that dyslexics ... seem to fail in elementary school learning while excelling at the broader level of graduate school. Many whose stories he recites were smashing successes in business. West urges that this is because of extra gifts in visual learning and thinking. He goes beyond praising dyslexics' hidden strengths in visual thinking and learning, their ability to see what others cannot see - he demands that we stop hiding the imaginative strengths of all children under their weaknesses in reading.' - Donald Lindberg, M.D., Director Emeritus, National Library of Medicine [6].

\section{Markle Scholars in Academic Medicine, Fifty-Year Reunion}

A major conference where Dr. Lindberg and I were on program provided insights into the history of medical education. The $50^{\text {th }}$ reunion of Markle Scholars in Academic Medicine occurred from September 17-19, 1998, in Phoenix, Arizona.

Other speakers included: Gerald M. Edelman, Scripps Research Institute (Nobel Prize winner), and Howard Gardner, Harvard Graduate School of Education (MacArthur Prize winner). Markle Scholars were professors identified by their medical school deans as the best teachers in the U.S. and Canada for several decades after World War II.

In my talk, I spoke primarily about visual thinking among creative scientists and some then-recent developments in computer graphic technologies. However, I also mentioned how visual thinking and associated innovation sometimes were linked to dyslexia and other related learning differences.

Remarkably, during the three-day conference, many (nearly one half of the attendees and their spouses) spoke to me about their dyslexia (two surgeons from Johns Hopkins, for example) or told stories of dyslexia among their family members or their more creative and innovative coworkers. 
As I look back, I am enormously grateful for the privilege of knowing Dr. Lindberg and his wife, Mary. Rightly, it is now often said both presided over the Golden Age of the National Library of Medicine.

Dr. Lindberg's vision was broad and deep, often including early consideration of diverse topics that only later became evident within the mainstream. Don took over a massive medical library primarily designed to serve various medical specialists - and using the newest technologies, he pushed the boundaries to serve the nation and, eventually, the world.

\section{References}

[1] West TG. In the mind's eye, creative visual thinkers, gifted dyslexics and the rise of visual technologies. $1^{\text {st }}$ ed. Amherst, NY.: Prometheus Books; 1991. 3rd Ed. Lanham, MD.: Rowman \& Littlefield Publishing Group; 2020.

[2] West TG. A return to visual thinking: new technologies, old talents and reversed expectations. Bethesda, MD.: NLM Board of Regents Meeting; May 26, 1993.

[3] West TG. Thinking like Einstein: returning to our visual roots with the emerging revolution in computer information visualization. Amherst NY.: Prometheus Books; 2004.

[4] Geschwind N, Galaburda AM. Cerebral lateralization: biological mechanisms, associations, and pathology. Cambridge, MA.: The MIT Press; 1987, p. 97-104.

[5] Tauber, AI, Podolsky SH. The generation of diversity: clonal selection theory and the rise of molecular immunology. Cambridge, MA.: Harvard University Press; 1997, p. 207.

[6] West TG. Seeing what others cannot see: the hidden advantages of visual thinkers and differently wired brains. Amherst, NY.: Prometheus Books; 2017. 